\title{
Ethnobotanical study of nedicinal plants in Ankober woreda, central Ethiopia
}

\author{
Daniel Kalu ${ }^{1}$ and Ali Seid*2 \\ ${ }^{1,2}$ Department of Biology, Bahir Dar University \\ alinabiot@yahoo.com, Cell Phone: (251) 0918767869
}

\begin{abstract}
Medicinal plants' diversity and associated indigenous knowledge in the Ankober district, central Ethiopia was studied from November, 2011 to May, 2012 using Ethnobotanical study approach. A total of 165 randomly selected informants aged 18 to 90 years were randomly selected from nine peasant associations (PAs) or kebeles. Of these, 34 were purposively selected as key informants. Data were collected using a semi-structured questionnaire, field observations and Focused Group Discussion (FGD). A total of 109 medicinal plant (MP) species from 56 families were described from the natural vegetation $(60.55 \%)$ and home gardens $(24 \%)$. Eighty three $(76.15 \%)$ medicinal plant species were used only to cure human diseases. Asteraceae and Lamiaceae were the two families containing the most cited species. MPs with high informants' consensus (HIC) were: Maesa lanceolata, Foniculum vulgare, Croton macrostachyus, Calotropis procera and Grewia ferruginea. Scabies, ring-worm and leishmaniasis were the top common diseases treated using the traditional use of medicinal plants. Knowledge of indigenous MP use significantly correlated increase with age. The existing common threats were identified by participatory approach. Awareness creation, motivating traditional healers to wisely use medicinal plants and availing their knowledge through proper negotiations are recommended.
\end{abstract}

Key words: Amhara Region, Ethiopia, Ethnobotany, Ethnomedicine, Medicinal Plants

DOI: http://dx.doi.org/10.4314/ejst.v7i2.4

\section{INTRODUCTION}

Medicinal plants have been globally used for millennia by indigenous people to get relief from illness beauty care as well as spiritual aspects (Hawkins, 2008). This is true in East African countries where medicinal and aromatic plant resources with high potential are used in the production of diverse herbal products at industrial scale (Ermias Dagne, 2003). Ten to twelve percent of the flora of Ethiopia is estimated to be endemic, many of them with aromatic and medicinal value (Endalew Amenu, 2007; IBC, 2007) providing traditional uses to a multiplicity of ethnic groupings with complex cultural diversity (Azene Bekele, 2007; IBC, 2007).

Since, indigenous medicines are relatively inexpensive, locally available, and are usually readily accepted by the local people, several African and Asian nations are increasingly introducing traditional medicine to their public health care programs (Agrawal, 2009).
In Ethiopia, about $70 \%$ of human and $90 \%$ of livestock population depend on traditional medicine (Endalew Amenu, 2007).

In many developed countries, increased use of complementary and alternative medicine (CAM) indicates that factors other than tradition and cost are at work (WHO, 2002). The progress made in medicinal plant use has identified plants serving as drug precursors, and/or pharmacological probes (Balick and Cox, 1996). About half the world's medicinal compounds are still derived or obtained from plants and they may give the chemical blueprints for the development of related synthetic drugs (Hamann, 1991). It is therefore, important to conserve the genetic material for future drug development programs (Agrawal, 2009). Many endemic medicinal plant species restricted to Ethiopia are of great concern. Medicinal plants and associated indigenous knowledge are under risk, mainly because of agricultural expansion, deforestation, fuel wood harvesting, overgrazing and urbanization (Getu Alemayehu, 2010; Moa Mergasa, 2010;

\footnotetext{
*Corresponding author

(C) This is an Open Access article distributed under the terms of the Creative Commons Attribution License (http://creativecommons.org/licenses/CC BY4.0)
} 
Nurya Abdurhman, 2010; Mohammed Adefa and Berhanu Abraha, 2011). Besides, cultural transformation occurring before the documentation of medicinal plant use knowledge is an important challenge in the conservation of medicinal plants that ethnobotanical research is concerned about (Balick and Cox, 1996).

In Ethiopia, a number of ethnobotanical researches have documented the declining indigenous knowledge held by traditional societies living in different parts of the (WHO, 2002; Haile Yineger and Delenasaw Yewhalaw, 2007; Endalew Amenu, 2008; Ermias Lulekal et al., 2008) country. The people of Ankober lead a traditional way of life, but no ethnobotanical research has been so far made in the area. Thus, this investigation of medicine plants and associated knowledge is believed to fill a gap in knowledge and hence, contribute to biodiversity conservation. The major objective of this research was documenting medicinal plants' diversity and the associated indigenous knowledge and identifying the major threats to MPs.

\section{MATERIALS AND METHODS}

\section{Description of the Study Area}

The Ankober Woreda (District) is found in the North Shoa zone of the Amhara Regional State, Ethiopia partly forming the western escarpment of the Great Rift Valley. It is located at the eastern edge of the Ethiopian central highlands (Figure 1). The population of Ankober Wereda is about 76,510 (CSA, 2007). The Woreda has two major ethnic groups, namely Amhara (92.77\%), and Argoba (7.04\%).

\section{Data Collection and Analysis}

A reconnaissance survey was carried out from October 2-9, 2011, in order to have an overview of the plant assemblages ('emic' or cultural vegetation classification) and determine the data collection methods. Ethnobotanical data were collected using a semi-structured questionnaire, key informants interview, field observation, guided field walk and Focused Group Discussion made in local language as recommended in (Balick and Cox, 1996; Cunningham, 2001; Alexiades, 1996; Martin, 1995). Information gathered includes: medicinal value, plant parts used, methods of preparation, route of administration, human and /or animal diseases treated, growth habit, and causes of threats to medicinal plants.

Appropriate herbarium specimens were collected and identification was made with the help of field guides and floras, comparison and experts determination

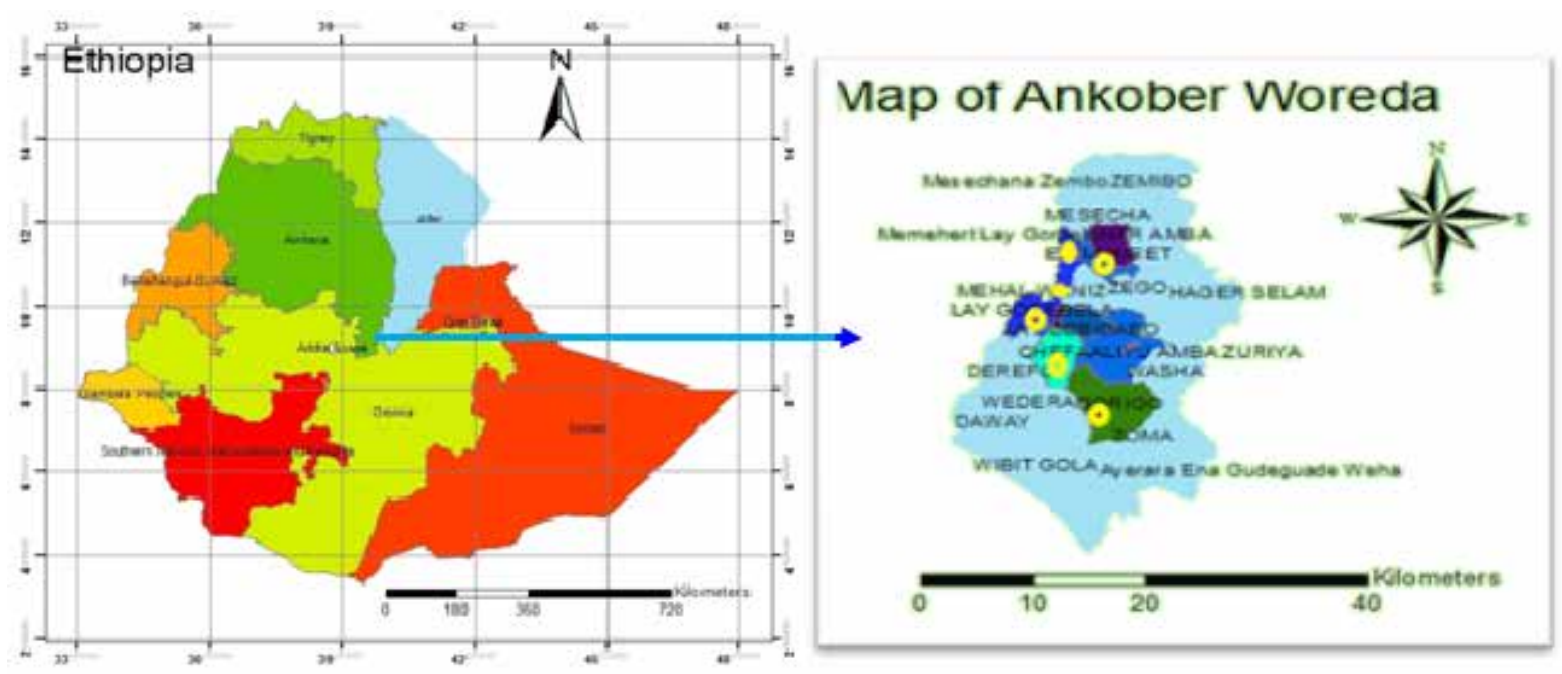

Figure1. Map of the study area, Ankober District (Woreda), and $\mathbf{\square}$ Sampled Kebeles (Source: http://www. maplandia.com/ethiopia/amhara/north-shewa/ankober) 
in the National Herbarium, and taxonomic key using flora books of Ethiopia and Eritrea (Hedberg and Edwards, 1989; Phillips, 1995; Edwards et al., 1995, 1997, 2000; Hedberg et al., 2003, 2006; Mesfin Tadesse, 2004)

A total of 165 informants, twenty seven from the six target PAs (kebeles) and three informants preferentially selected from Alyuamba kebele were the study subjects. The later were selected, based on the recommendation of local elders, health workers, development agents, local administrators and villagers' recommendation. The 34 Key informants were purposively elected from those informants selected before.

\section{Data Anaylsis}

Descriptive statistics including preference ranking, paired comparison, fidelity level index, informant consensus, and diversity indices were computed using Microsoft Excel (2007) spread sheet. Pearson correlation coefficient was calculated to determine the relationship between informants and medicinal plant knowledge. Fidelity level (FL) for the most frequently reported diseases or ailments was calculated as:

$$
\mathrm{FL}=\frac{N p}{N} * 100 \frac{N p}{N} * 100
$$

Where: $\mathrm{N}_{\mathrm{p}}$ is the number of informants that claim a use of a plant species to treat a particular disease, and $\mathrm{N}$ is the number of informants that use the plants as a medicine for any given disease.

\section{RESULTS AND DISCUSSION}

\section{Emic and Etic Categorization of Vegetation}

The study discovered that medicinal plants were named emically based on different criteria including habitat such as Rubes steudneri 'Yedega-enjori' (highland berry), Rubus apetalus 'Yekola-enjori' (lowland berry); plant color; healers perceptions of plants species (local verity) medicinal values and after their disease name that it heals. Such names are 'Ymich Medanit' (febrile healer) for Ocimum lamifolium, 'Yedengetagna Medanit' (Acute Healer) for Cucumis ficifolius and 'Entil Betis' (Tonsil Healer) for Ajuga integrifolia. Each medicinal plant recorded in this study has a well known vernacular name indicating its popularity as a medicinal plant.

Based on the researchers ideas about what people know about plants (Etic Categorization or ecological communities), the vegetation types of the study area are of two types. The highland vegetation zones characterized by Erica arborea and Chloris sp., is found at altitude above $3000 \mathrm{~m}$ a.s.l., forming the afro-alpine vegetation. The second vegetation is Eucalyptus globules and mixed vegetation where a number of medicinal plants are located. The medicinal plants knowledge distribution is found to have significant correlation $(\mathrm{r}=0.86)$ with age of healers.

\section{Medicinal Plants Diversity}

In this study a total of 109 medicinal plant species, belonging to 56 families are documented. Astereaceae and Lamiaceae were the most dominant plant families, represented by 10 species each, followed by Solanaceae and Euphorbiaceae each represented by 7 species. The top two plant families are also have higher contribution as reported by different authors in medicinal plant studies carried out elsewhere (Hawkins, 2008; Nurya Abdurhman, 2010; Tesfaye Awas and Sebsebe Demissew, 2009; Ermias Lulekal et al., 2008).

In terms of growth habit $47(43.12 \%)$ of the medicinal plants were shrubs (Figure 2) and all species with local names indicated the popularity and importance of the plants in the study area. Some of them are endemics, and include Inula confertiflora, Laggera tomentosa, Lippia adoensis, Lobelia rhynchopetalum, 
Solenecio gigas, Thymus schimperi and Urtica simensis accounting $6.42 \%$ of the total number of medicinal plants recorded in the study. Of the endemics Lobelia rhynchopetalum is reported as a threatened species (Vivero et al., 2005).

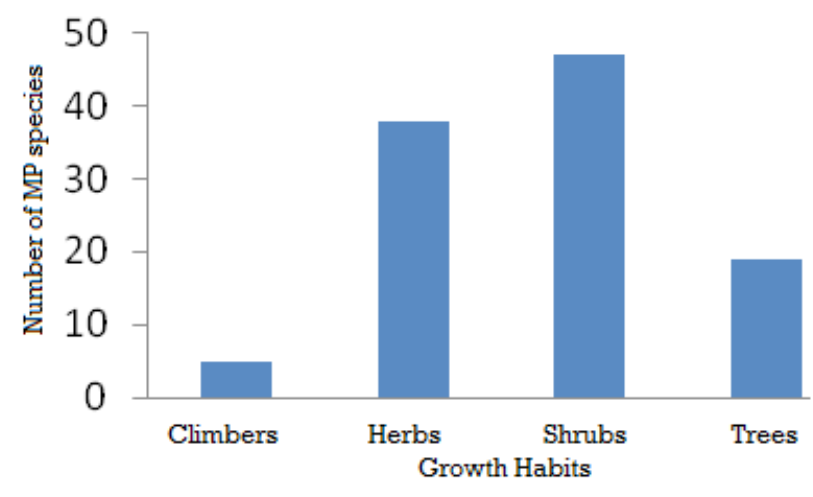

Figure 2. Proportions of Medicinal Plants by Growth Habits

Analysis of growth form revealed that shrub constitute the largest category with $47(43.12 \%)$ species followed by herbs with 38 (34.86\%) species (Figure 2 ) which is in agreement with the resulst of other researchers (Fisseha Mesfin, 2007; Ermias Lulekal et al.,2008; Getu Alemayehu, 2010). However the results were contrary to Endalew Amenu (2007) and Tesfaye Awas and Sebsebe Demissew, 2009) who documented larger proportion of herbaceous medicinal plants.

The majority 67 (60.55\%) of medicinal plant species were collected from natural habitats 27 (24.77\%) from home-garden and the remaining from both indicating natural habitats are the main source of medicinal plants like in other studies (Fisseha Mesfin, 2007; Ermias Lulekal et al., 2008; Tesfaye Hailemariam et al., 2009; Getu Alemayehu, 2010; Moa Mergasa, 2010). In terms of ailments, 83 (76.15\%) species were used for human, 15 (13.76) species for both livestock and human ailments and the remaining 11 (10.09\%) species for livestock and consolidates the works of (Endalew Amenu. 2007; Ermias Lulekal et al., 2008; Tesfaye Hailemariam et al., 2009; Moa Mergasa,
2010; Nurya Abdurhman, 2010) who also reported more number of medicinal plant use for human ailments than for livestock.

\section{Medicinal Pant Utilization}

\section{Pant Parts Used and Remedy Preparations}

The very common medicinal plants are used by self collection and preparation. However, MPs knowledge in Ankober showed a significant correlation $\left(\mathrm{R}^{2}=0.858\right)$ with age of informants. Plant used by elderly members of the community was higher than youngsters. Many informants in age category between (51- 90) were able to list more than 48 medicin independently but the other two lower age categories were not able to cite more than few plants. This could be related to a higher degree of cultural contact and experience of the elderly members and/or the effects of both cultural transformation, access to modern drags and lack of awareness.

Leaves were the most frequently used plant part used in $63(45.65 \%)$ cases, followed by roots in $23(16.67$ $\%$ ) cases and fruits used in 15 (10.87\%) cases. Other studies (Tesfaye Hailemariam et al., 2009; Behailu Etana, 2010; Moa Mergasa, 2010; Nurya Abdurhman, 2010) had reported similar findings, contrary to Ermias Lulekal et al. (2008). As revealed in this study, collecting leaves for remedies could have lesser impact than collecting roots and stems.

The method of processing 49 (34.51\%) include chopping and harmonizing in water and/or other solvents; $27(19.01 \%)$, crushing and squeezing extraction 22 (15.49\%), powdering and 10 (7.04\%) boiling. Solvents like water, local alcoholic beverages such as, 'Tella' (local beer) and/or 'Teji' (fermented honey), and milk were used to make dissolved and wet preparations. In most cases water was used as a solvent, but semi solid preparations were also made with butter and honey. Moreover, sugar, honey, tea, coffee were 
added for taste, especially when remedies are administered orally, beside some animal products such as better, chicken fat and essential organs of selected species.

\section{Diseases Treated, Route of Administration and Dosage of Medicinal Plants}

Out of the 109 medicinal plant species, $76.15 \%$ are used to treat about 42 different types of human ailments (Table 1). There were a total of 142 types of treatment preparations. The routes of administration were oral 66 (46.48\%), dermal 59 (41.55\%), nasal $6(4.23 \%)$, ocular $5(3.52 \%)$, through ears and both dermal and oral each 2 (1.41\%). However, only single preparation administerd through anal and applied on tooth. As reported by others, oral administration is the major root of delivery (Dawit Abebe and Ahadu Ayehu, 993; Behailu Etana, 2010; Moa Mergasa, 2010; Gidey Yirga and Samuel Zeraburk, 2011).

Depending on the age and health condition of the patients, the dosage measurements were spoon, Kuntit (pinch), Chibit (Fist) for powdered preparation, and 'Sêni' (Coffee Cup), 'Tassa' (Can), and 'Birchiko' (Glass) for liquid preparation. Children are given less doses than adults, as less as one fourth of a coffee cup compared to an adult that may be given up to one Tassa depending on the type of illness and treatment. The dosage is however, greater for animals than for human beings.

The informants in the study area reported that some of the MPs including Hagenia abyssinica, Phytolacca dodecandra, Verbasicum siniaticum, Euphorbia candelabrum and Croton macrostachyus are poisonous to human if not handled with proper care. Though these MPs do have side effects, they are also effective against human and animal ailments, hence, the emphases must shift to how much the local people are aware of side effects of using MPs.

The study revealed that though measurement units lack precision, healers routinely measure the plant
Table 1. List of human and livestock diseases that are treated using plants

\begin{tabular}{llcc}
$\begin{array}{l}\text { Disease } \\
\text { treated }\end{array}$ & $\begin{array}{l}\text { Local name of } \\
\text { The disease }\end{array}$ & $\begin{array}{c}\text { No. of } \\
\text { species } \\
\text { used }\end{array}$ & $\begin{array}{c}\text { Percent } \\
\text { of plants }\end{array}$ \\
\hline Acute disease & Dingetegna & 14 & 12.84 \\
Body swelling & Ebach & 12 & 11.01 \\
Diarrhea & Tekimat & 10 & 9.17 \\
Herpes zoster & Almaz balechira, & 10 & 9.17 \\
Rabies & Yewush beshita & 10 & 9.17 \\
Sore throat & Entilmewured & 8 & 7.33 \\
Eczema & Chife & 8 & 7.34 \\
Jaundice & Wof (gubet) & 8 & 7.34 \\
Hemorrhoid & Kintarot & 8 & 7.34 \\
Bleeding & Yedemabinet & 7 & 6.42 \\
Belly blotting & Entako (hod & 7 & 6.42 \\
Common cold & yeminefa) & & \\
Gunfan & 6 & 5.50 \\
Dandruff & Forefor & 5 & 4.59 \\
Skin infection & Megagna & 5 & 4.59 \\
Hypertension & Demgfit & 5 & 4.59 \\
Abdominal & Kurtet & 5 & 4.59 \\
Fibril illness & Michi & 5 & 4.59 \\
Evil spirit & Buda & 5 & 4.59 \\
\hline & & & \\
\hline
\end{tabular}

part and the amount of water that will be added to prepare the plant remedy. The most widely used measuring unit reported in this study was the tip part of forefinger ('atiq)'. As reported by others, the amount and rates of remedy prescribed by a healer depends on age, physical variation and level of sickness (Ermias Lulekal et al., 2008, Haile Yineger and Delenasaw Yewhalaw (2007). Even though, almost all informants have developed awareness of the toxic nature of some plants, especially when administered in large doses, they prefer MPs than modern drugs for some diseases pointing that the dose should be refined for those preferred MPs. To control the harmful effects of the doses it was also found that homogenous solution of 'Beso' (tossed barley preparation) and in few cases tella' (local beer) has been given as antidotes in some cases. 


\section{Important Medicinal Plants in Ankober}

Informant consensus values were made to identify important medicinal plants (Table 2). The method is used to indicate that particular species that can be used to solve particular health problems and specific MPs used for several health problems (Martin, 1995). Some of MPs recorded in this study have also been used in other parts of Ethiopia as reported in (Fisseha Mesfin, 2007; Tilahun Teklehaymanot and Mirutse Giday, 2007; Ermias Lulekal et al., 2008; Getu Alemayehu, 2010) indicating their pharmacological significance. Higher informant consensus warrants fur- ther ethnopharmacological studies of medicinal plants for identifying active ingredients of the plants.

\section{Direct Matrix Ranking For Multipurpose Medicinal Plants}

The ranking exercise showed that Olea europea is the top multipurpose MP, followed by Myrica salicifolia and Dodonia angustifolia respectably. Table 3 shows the direct matrix ranking of six plant species by three key informants with seven criteria for each plant species.

Table 2. Medicinal plants of higher Informant Consensus Factor (ICF) for treatment

\begin{tabular}{lcclc}
\hline Scientific Name & No of species & N cited & Disease treated & ICF Value \\
\hline Maese lanceolata & 1 & 45 & Scabies & 1.00 \\
Foniculum vulgare & 1 & 7 & Retention of urine & 1.00 \\
Croton macrostachyus & 2 & 55 & Tinea corporis & 0.98 \\
Calotropis procera & 3 & 43 & Leishmaniasis & 0.95 \\
Leucas abyssinicum & 3 & 43 & To expel leech & 0.95 \\
Grewia ferruginea & 2 & 19 & Retained placenta & 0.94 \\
Croton macrostachyus & 4 & 56 & Gonorrhea & 0.94 \\
Inula confertiflora & 4 & 35 & Tinea nigra & 0.91 \\
Achyranthes aspera & 4 & 27 & Traumatic Wound & 0.88 \\
Justicia schiperiana & 8 & 52 & Jaundice & 0.86 \\
\hline
\end{tabular}

Table 3. Direct matrix ranking of six selected multi use MPs with use diversity

\section{Medicinal plants}

\begin{tabular}{lcccccc} 
Main use & C.macrosttachus & D.angustifolia & O. europea & H. abyssinica & J. procera & M. salicifolia \\
\hline Construction & 8 & 9 & 14 & 14 & 15 & 11 \\
Fire wood & 9 & 14 & 14 & 8 & 13 & 11 \\
House utensils & 6 & 6 & 11 & 14 & 14 & 13 \\
Forage & 6 & 13 & 14 & 3 & 5 & 13 \\
Tooth brush & 0 & 10 & 15 & 7 & 0 & 9 \\
Medicine & 15 & 12 & 14 & 15 & 9 & 14 \\
Farming tools & 8 & 9 & 14 & 11 & 8 & 10 \\
Grand total & 52 & 73 & 96 & 72 & 64 & 78 \\
Rank & $6^{\text {th }}$ & 3 rd & $1 \mathrm{st}$ & $4^{\text {th }}$ & $5^{\text {th }}$ & 2 nd
\end{tabular}

Key: $5=$ Excellent, $4=$ Very good, $3=$ Good, $2=$ Less, $1=$ least and $0=$ Not used 
Table 4. List of nine MPs with highest Fidelity level value

\begin{tabular}{lllc}
\hline Plant species & Local name & Therapeutically use & Fidelity Level(FL) \\
\hline Kanahia laniflora & Tifrindo & Acute disease & $100 \%$ \\
Euphorbia tirucalli & Kinchib & Leishmania & $100 \%$ \\
Xanthium strumarium & Fikrutena & Tinea nigra & $100 \%$ \\
Thalictrum rhynchocarpum & Sirebizu & Pest entered ear & $100 \%$ \\
Endostemen tereticaulia & Ena & Tinea nigra & $100 \%$ \\
Dichrostachys cinerea & Ader & Scorpion bite & $100 \%$ \\
Hagenia abyssinica & Kosso & Tinea saginata & $100 \%$ \\
Vernonia amygdalina & Girawa & Skin disease & $100 \%$ \\
Grewia ferruginea & Lenkuata & Retained placenta & $100 \%$
\end{tabular}

Fidelity Level Value Ranking of Medicinal Plants

Computation of the fidelity level values of medicinal plants showed that ten MPs with highest fidelity level (Table 4).

\section{Threat to Medicinal Plants}

The causes of threats to MPs can be grouped in to natural or anthropogenic factors. The threats to medicinal plants were scaled 1-5 and have been found that agricultural expansion, deforestation, overgrazing, charcoal and fire wood collection were major threats to medicinal plants in descending order (Ta- ble 5). Agricultural expansion was the most serious threat in the highlands and followed by deforestation and overgrazing, eucalyptus plantation and fire wood and house hold material harvesting in the mid-altitude mixed vegetation. While drought is mentioned as a big threat with highly negative impact on plant diversity, there was little interest from youngsters to learn about traditional healing and retain the MPs' knowledge. This is due to lack of awareness, education and thinking westernization as civilization. The expansion of clinics and health facilities could have intensified cultural transformation. Moreover, adulteration and acculturation are emerging challenges.

Table 5. Priority ranking of perceived threats to MPs

\begin{tabular}{|c|c|c|c|c|c|c|c|c|c|c|c|c|}
\hline \multirow[b]{2}{*}{ Major Threat } & \multicolumn{9}{|c|}{ Respondents (R1-R9) } & \multirow[b]{2}{*}{ Total } & \multirow[b]{2}{*}{$\%$} & \multirow[b]{2}{*}{ Rank } \\
\hline & $\overline{\mathrm{R}_{1}}$ & $\mathrm{R}_{2}$ & $\mathrm{R}_{3}$ & $\mathrm{R}_{4}$ & $\mathrm{R}_{5}$ & $\mathrm{R}_{6}$ & $\mathrm{R}_{7}$ & $\overline{\mathrm{R}_{8}}$ & $\overline{\mathrm{R}_{9}}$ & & & \\
\hline Agriculture Expansion & 5 & 4 & 5 & 5 & 4 & 4 & 5 & 5 & 5 & 42 & 17.87 & $1^{\text {st }}$ \\
\hline Over grazing & 3 & 4 & 5 & 4 & 4 & 5 & 3 & 3 & 2 & 33 & 14.04 & $2^{\text {nd }}$ \\
\hline Construction & 5 & 5 & 3 & 4 & 4 & 2 & 4 & 2 & 4 & 33 & 14.04 & $2^{\text {nd }}$ \\
\hline Eucalyptus plantation & 4 & 5 & 2 & 3 & 3 & 3 & 4 & 5 & 2 & 31 & 13.19 & $3^{\mathrm{rd}}$ \\
\hline Fire wood & 2 & 1 & 1 & 2 & 5 & 4 & 3 & 4 & 5 & 27 & 11.49 & $4^{\text {th }}$ \\
\hline Drought & 4 & 3 & 4 & 2 & 2 & 1 & 2 & 1 & 4 & 23 & 9.79 & $6^{\text {th }}$ \\
\hline Medicinal plant Trade & 3 & 2 & 3 & 2 & 1 & 2 & 2 & 3 & 3 & 21 & 8.94 & $7^{\text {th }}$ \\
\hline Household Equipment & 4 & 3 & 2 & 4 & 2 & 3 & 1 & 2 & 4 & 25 & 10.64 & $5^{\text {th }}$ \\
\hline
\end{tabular}




\section{CONCLUSIONS}

One hundred and nine medicinal plant species in 56 families for Ankober Woreda indicates a relatively high MPs diversity and existence of indigenous knowledge relative to its small size. As reported from other places in Ethiopia, Asteraceae and Lamiaceae are the two plant families containing the most cited medicinal plant species. The local people and traditional healers still knew distribution, medicinal use and conservation status of MPs. In addition to their medicinal values, MPs have been used for different purposes. This together with the shortage of farmlands is major threat to both plants and indigenous knowledge in the woreda. There is little interest from youngsters to learn about traditional healing. Thus, facilitating the sustainable utilization of MPs and indigenous knowledge of the Ankober people need a concerted efforts and timely actions.

\section{ACKNOWLEDGEMENTS}

We greatly acknowledge the local people of Ankober, particularly the traditional healers who shared their knowledge on medicinal plants and Dakon Abiy Tilahun for giving pertinent advice during field works. We are grateful for the Ministry of Education and Bahir Dar University for partly funding the cost of the research; and the National Herbarium for their cooperation during herbarium work.

\section{REFERENCES}

Agrawal, S. (2009). Advance in Medicinal Plants. Oxford Book Company, India.

Alexiades, M. (1996). Collecting Ethnobotaincal Data, an Introduction to Basic Concepts and Techniques. In: Selected Guide line for Ethnobotanical research: A Field Manual, PP. 53-94 (Alexiades, M. and Sheldon, J. W., eds.). The New York Botanical Garden.

Azene Bekele-Tesemma. (2007). Useful trees and shrubs of Ethiopia: Identification, Propagation and Management for 17 Agroclimatic Zones. In: RELMA in ICRAF Project World Agro forestry Centre, East Africa Region (Tengnäs, B., Ensermu Kelbesa, Sebsibe Demissew and Maundu, P. Eds.), Nairobi, Kenya.

Balick, M.J., and Cox, P.A. (1996). Plants, people and culture: Science of Ethnobotany. New York, USA.

Behailu Etana. (2010). Ethnobotanical Study of Traditional Medicinal Plants of Goma Wereda, Jima Zone of Oromia Region. M.Sc., Thesis, Addis Ababa University, Ethiopia.

Central Statistics Authority (CSA). (2007). Population of Ethiopia, Amhara Region. Vol. I: part I. Addis Ababa, Ethiopia.

Cunningham, A.B. (2001). Applied Ethnobotany: People, wild plant use and conservation. Earthscan Publications Ltd. London.

Dawit Abebe and Ahadu Ayehu, (1993). Medicinal plants and Enigmatic Health practices of northern Ethiopia. Berhanina Selam Printing Enterprise, Addis Ababa.

Edwards, S., Mesfin Tadesse and Hedberg, I. (eds) (1995). Flora of Ethiopia and Eritrea, Vol. 2 (2), Canellaceae to Euphorbiaceae. The National Herbarium, Addis Ababa University, Addis Ababa and Uppsala.

Edwards, S., Sebsebe Demissew, Hedberg, I. (eds) (1997). Flora of Ethiopia and Eritrea, Vol. 6, Hydrocharitaceae to Arecaceae. The National Herbarium, Addis Ababa University, Addis Ababa and Uppsala.

Edwards, S., Mesfin Tadesse and Sebsebe Demissew (eds) (2000). Flora of Ethiopia and Eritrea, Vol. 2 (1), Magnoliaceae to Flacourtiaceae. The National Herbarium, Addis Ababa University, Addis Ababa and Uppsala. 
Endalew Amenu. (2007). Use and management of medicinal plants by indigenous people of Ejaji area (Chelya Woreda) west Shoa. M.Sc., Thesis, Addis Ababa University, Ethiopia.

Ermias Dagne. (2003). the status of herbal products: the case of East Africa. UNDP Organization and the International Centre for Science

Ermias Lulekal, Ensermu Kelbessa, Tamrat Bekele and Haile Yineger. (2008). An Ethnobotanical study of medicinal plants in Mana Angetu District, Southeastern Ethiopia. Journal of Ethnobiology and Ethnomedicin 4:10 doi:10.1186/1746-4269-4-10.

Fisseha Mesfin. (2007). An ethnobotanical study of medicinal plants in Wonago Wereda, SNNPR. M.Sc. Thesis, Addis Ababa University, Ethiopia.

Getu Alemayehu. (2010). Ethnobotanical study on medicinal plants used by indigenous local communities in Minjar-shenkora Wereda, North Shewa Zone. M.Sc. Thesis, Addis Ababa University, Ethiopia.

Gidey Yirga and Samuel Zeraburk. (2011). Ethnobotanical Study of Traditional Medicinal Plants in Gindeberet District, Western Ethiopia. Mediterranean Journal of Social Sciences 2 (4).

Haile Yineger and Delenasaw Yewhalaw. (2007). Traditional Medicinal Plant Knowledge and Use by Local Healers in Sekoru District, Jimma Zone, Southwestern Ethiopia. Journal of Ethnobiology and Ethnomedicine 3(24) doi:10.1186/1746-4269-3-24.

Hamann, O. (1991). The joint IUCN-WWF plants conservation program and its interest in medicinal plants. In: Conservation of Medicinal Plants. PP. 13- 25. (Kerele, O. Vernon, H. and Synges, H. Eds.), Cambridge University, USA and High Technology.
Hawkins, B., (2008). Plants for life: Medicinal plant conservation and botanic gardens. Botanical Gardens Conservation International, Richmond, U.K.

Hedberg, I., Edwards, S. (eds) (1989). Flora of Ethiopia, Vol. 3, Pittosporaceae to Araliacae. The National Herbarium, Addis Ababa University, Addis Ababa and Uppsala.

Hedberg, I., Edwards, S., Sileshi Nemomissa (eds) (2003). Flora of Ethiopia and Eritrea. Vol 4 (2), Apiaceae to Dipsaceae. The National Herbarium, Addis Ababa University, Addis Ababa and Uppsala.

Hedberg, I., Ensermu Kelbessa, Edwards, S., Sebsebe Demissew, Persson, E. (eds) (2006). Flora of Ethiopia and Eritrea. Vol 5, Gentianaceae to Cyclocheilaceae. The National Herbarium, Addis Ababa University, Addis Ababa and Uppsala.

Institute of Biodiversity Conservation (IBC). (2007). Country Report on the state of plant genetics resources for Food and Agriculture Organization. Addis Ababa, Ethiopia.

Martin, G. J. (1995). Ethnobotany: A Methods

Manual. Chapman and Hall, London.

Mesfin Tadesse (2004). Asteraceae (Compositae). In: Hedberg I, Friis I, Edwards S (eds) Flora of Ethiopia and Eritrea. Vol 4 (1). The National Herbarium, Addis Ababa University, Addis Ababa and Uppsala.

Moa Mergasa. (2010). Ethnobotanical study of medicinal plants in Wayu Tuka Woreda, East Wollega, Oromia Region. M.Sc., Thesis, Addis Ababa University, Ethiopia.

Mohammed Adefa and Berhanu Abraha. (2011). Ethnobotanical survey of traditional medicinal plants in Tehuledere district, south Wollo, Ethiopia. Journal of Medicinal Plants Research 5:26. 
Nurya Abdurhman (2010). Ethnobotanical Study of medicinal plants used by local people in Ofla Wereda, southern zone of Tigray Region. M.Sc. Thsesis, Addis Ababa University, Ethiopia.

Phillips, S. (1995). Poaceae (Gramineae). In: Hedberg I, Edwards S (eds). Flora of Ethiopia and Eritrea, Vol. 7. The National Herbarium, Addis Ababa University, Addis Ababa and Uppsala.

Tesfaye Awas and Sebsebe Demissew (2009). Ethnobotanical study of medicinal plants in Kafficho people, South-western Ethiopia. In: Proceedings of the $16^{\text {th }}$ International Conference of Ethiopian Studies (Ege s., Aspen H., Birhanu Teferra and Shiferaw Bekele Eds.), Trondheim, Norway.

Tesfaye Hailemariam, Sebsebe Demissew and Zemede Asfaw, (2009). An ethnobotanical study of medicinal plants used by local people in the lowlands of Konta Special Woreda, southern nations, nationalities and peoples regional state, Ethiopia. Journal of Ethnobiology and Ethnomedicine 5:26 doi: 10.1186/1746-4269-5-26.

Tilahun Teklehaymanot and Mirutse Giday. (2007). Ethnobotanical study of medicinal plants used by people in Zegie Peninsula, Northwestern Ethiopia. Journal of Ethnobiology and Ethnomedicine 3:12 doi: 10.1186/1746-4269-3-12.

Vivero, J.L., Ensermu Kelbessa and Sebsebe Demissew. (2005). the Red List of Endemic Trees and Shrubs of Ethiopia and Eritrea. Fauna and Flora International, Cambridge, UK.

World Health Organization (WHO. (2002). WHO Traditional Medicine Strategy 20022005. World Health Organization, Geneva, Switzerland. 